\title{
Osmanlı Devleti’nde Modernleşme Girişimlerine Bir Örnek: Lisan Mektebi
}

\author{
An Example to Modernisation Attempt in Ottoman State: \\ Language School
}

\begin{abstract}
Sezai BALCI*
$\ddot{o} z$

Osmanl modernleşmesinin önemli teşebbüslerinden biri de devlet memurlarının yabancı dil ögrenmeleri meselesidir. Osmanlı Devleti'nde tercümanllk gibi yabancı dil bilgisini gerektiren memuriyetler 1821'e kadar Fenerli Rum Beylere bırakılmış ve bu tarihten sonra da Müslümanlar bu göreve getirilmiştir. Tercüme Odası'nın 1860'lardan sonra Osmanlı idari teşkilatında yabancı dil öğretilen bir okul olma misyonunu yitirmesiyle Lisan Mektebi açılmıştır. Bu çalışmada, birçok defa açıllp kapatılan Lisan Mektebi'nin kuruluşu, ders programları ve ögretim kadrosu belgelere dayalı olarak incelenmiştir.

Anahtar Kelimeler: Osmanl, Lisan Mektebi, Eğitim

Abstract

One of the important attempts of the Ottoman Modernization is the problem of the state offical's learning foreign languages. In Ottoman State pozitions requiring foreign language knowledge such as interpretership had been left to Phanariot Greeks until 1821, and after this date Muslim were appointed to these positions. Having The Translation Office lost its mission in Ottoman bureucracy as a school that teaches foreign languages after 1860's, The Language School was opened. In this study foundation, curriculum, and faculty of the Language School, which was opened and closed several times, has been examined based on documentary materials.
\end{abstract}

Keywords: Ottoman, Language School, Education 


\section{Giriş}

XVII. yüzyılda Osmanlı Devleti'nde belirgin bir şekilde siyasi, idari, ekonomik, toplumsal ve askeri bakımdan duraklama başlamıştır. $\mathrm{Bu}$ duraklamayı takiben devletin bütün kurumlarında bozulma ile birlikte çözülme de ortaya çıkmıştır. Osmanlı Devleti, XVII. yüzyılda batıda Almanlarla ve doğuda İranla uzun ve yorucu savaşlarla karşı karşıya kalmış, XVIII. yüzyılda bu savaşlara Rusya da katılmıştır. 1683 Viyana yenilgisini izleyen 16 yıl boyunca yapılan savaşlar ve kaybedilen topraklar bu bozulmayı daha da belirginleştirmiştir. XVIII. yüzyılın başından itibaren Osmanlı yönetimi kaybedilen toprakları kazanma arzusuna kapılmış, savaşlarda görülen başarısızlık askeri sınıfın yerine kalemiye memurlarının önem kazanmasına yol açmıştır. Özellikle Reisiülküttap Mehmed Rami Efendi'nin Sadrazamlığa atanması bunun en önemli ve en belirgin göstergesidir.

Lale devrinde devlet Batı'ya açılmış Paris, Viyana, Varşova ve Rusya'ya yollanan elçiler yalnızca diplomatik görüşmelerde değil Batı diplomasisi, kültürü, sanatı, sanayii, tarımıyla birlikte askeri ve teknolojik gücü hakkında bilgi edinmeye ve bunları birer rapor halinde sunmaya başlamışlardır. $\mathrm{Bu}$ raporlar içinde en önemlisi Yirmisekiz Mehmet Çelebi'nin sefaretnamesidir. ${ }^{1}$ Aynı zamanda Lale devri Osmanlı düşünce hayatının uyanışına da zemin hazırlamıştır. Bu dönemde edebi eserler başta olmak üzere kültürel ve bilimsel eserlerin Arapça ve Farsça'dan Türkçe'ye çevrilmesi için çalışmalar yapılmıştır. ${ }^{2}$ Bu dönemde matbaanın açılması ve sayısı az da olsa kitap basılması, Yalova' da ilk kâğıt fabrikasının kurulması önemli adımlardır. ${ }^{3}$

Osmanlı modernleşmesinin ilk ciddi teşebbüsü III. Selim'le başlayan Nizam-1 Cedid hareketidir. III. Selim, XVIII. yüzyıl ıslahatçı geleneği içinde yetişmiş, veliaht iken ihtilal öncesi Fransası'nın son kralı olan XVI. Louis ile mektuplaşmış ve ondan tavsiyeler almıştır. Nizam-1 Cedid ıslahatı ilk önce askeri alanda görülmüsştür. Deniz Mühendishanesi'nin yanında Humbarahane (1792) ile Mühendishane-i Berr-i Hümayun (1794) okulları açılmış, bu okullarda ders vermeleri için başta Fransa olmak üzere birçok Avrupa ülkesinden yabancı uzmanlar getirilmiş ve Arapça'nın yanında

*Yrd. Doç. Dr. Giresun Üniversitesi, Fen-Edebiyat Fakültesi, Tarih Bölümü,sezaibalci@gmail.com.

${ }^{1}$ Yirmisekiz Çelebi Mehmed Efendi’nin Sefaretnamesi, (Yay. Haz. Beynun Akyavaş), Ankara 1993.

${ }^{2}$ Lale devrinde yapılan tercüme faaliyetleri için bkz. Taceddin Kayaoğlu, Türkiye'de Tercüme Müesseseleri, İstanbul 1998, s. 29-47.

${ }^{3}$ Türk matbaacılık tarihi ve gelişimi hakkında bkz. Selim Nüzhet Gerçek, Türk Matbaacılığı Müteferrika Matbaası, İstanbul 1939. 
Fransızca mecburi ders olarak okutulmaya başlanmıştır. ${ }^{4}$ XVIII. yüzyılın sonlarından itibaren askeri reformun ihtiyaçları yalnız yabancı uzmanların görevlendirilmesini değil, Batılı matematik ve diğer bilimsel eserlerin çevrilip basılması yolunu da açtı. Artık Osmanlılar yeni bilgilerini bir zamanlar aşağılamaya alışık oldukları "barbarların dilleriyle" öğrenmek zorundaydılar.

III. Selim'in önemli bir modernleşme girişimi de 1793 'te ilk daimi elçiliklerin Londra Viyana, Berlin ve Paris'te açılması olmuştur. ${ }^{5}$ Bu elçilik maiyetlerinde bulunan memurların bir kısmı Mahmut Raif Efendi ve Seyyit Mustafa gibi başta Fransızca olmak üzere bazı Batı dillerini, Batı toplumunun yaşam tarzlarını öğrenmişler, Avrupa'da hüküm süren devrimci fikirleri yakından tanımışlar ve Avrupa'nın çeşitli kesimleriyle ilişkiler kurmuşlardır. $^{6}$ Böylece yüzleri Batı'ya dönük aydın bürokrat tipinin tohumları atılmışıır. Bu zamana kadar dış politikanın yürütülmesinde birinci derecede aracı olan yerli Hristiyanların yanında Türklerin de yer almalarını sağlayacak ve gittikçe onların yerini dolduracak olan bir gelişmeye giden yollar açılmıştır. Avrupa ile devletin doğrudan doğruya teması demek olan bu teşebbüs Tanpınar' a göre "Batı'yı görmüş devlet adamlarl yetiştirmenin o devir için en iyi yolu"ydu.

Yabancı dildeki bu gelişmelerle birlikte Osmanlılar Batı dilleriyle ilgili bilgi edinme ve Avrupa'daki olaylar ve ilişkilerden haberdar olma konusunda hâlâ Divan-1 Hümayun Tercümanları'na bel bağlamak zorundaydılar. Bu durum 1821'de patlak verecek olan Yunan İsyanı'na kadar devam edecektir.

XIX. yüzyılın ortalarında bir Avrupa dilini bilmek, hükümet nezdinde bir kariyer elde etmeyi amaçlayan genç Türkler için vazgeçilmez bir nitelik haline gelecek ve bu dillerin öğrenildiği Tercüme Odası terfi ve iktidar olma yolunda ordu ile sarayın yanında yerini alacaktır.

\footnotetext{
${ }^{4}$ Enver Ziya Karal, Osmanlı Tarihi, c. 5, VI. baskı, Ankara 1994, s. 67 vd.; Çağatay UluçayEnver Kartekin, Yüksek Mühendis Okulu, İstanbul 1957, s. 492; Dil sorununda Türkçe'yi en çok zorlayan İtalyanca'nın yerini alan Fransızca olmuştur. Türk ve Avrupalıları ilgilendiren belgeler, Latince'nin diplomatik dil olduğu sürece, Latince kaleme alınmıştır. 1699 Karlofça ve 1718 Pasarofça Antlaşmaları Latince ve Türkçe; 1774 Küçük Kaynarca Antlaşması İtalyanca olarak kaleme alınmıştır. Bernard Lewis, Müslümanların Avrupa'yı Keşfi, (çev. İhsan Durdu), İstanbul 2000, s. 96.

${ }^{5} \mathrm{Bu}$ ilk elçiliklerin faaliyetleri için bkz. Ercüment Kuran, Avrupa'da Osmanlı İkamet Elçiliklerinin Kuruluşu ve İlk Elçilerin Siyasi Faaliyetleri (1793-1821), Ankara 1968.

${ }^{6}$ Mahmut Raif Efendi, daha sonra reisülküttaplık da yapmıştır. Kemal Beydilli-İ. Şahin, Mahmut Raif Efendi ve Nizam-ı Cedid'e Dair Eseri, Ankara 2001; Seyyit Mustafa hakkında bkz. Niyazi Berkes, Türkiye'de Çağdaşlaşma, (haz. Ahmet Kuyaş), 4.baskı, İstanbul 2003, s. 99 vd.

7 Ahmet Hamdi Tanpınar, Edebiyat Üzerine Makaleler, (haz. Zeynep Kerman), İstanbul 1969, s. 96.
} 


\section{Osmanlılarda Dil Öğrenme Geleneği}

Osmanlı Devleti'nde yabancı dil öğrenme geleneği üzerinde durmak yerinde olacaktır. Avrupa ülkeleri ve Japonya gibi Asya ülkeleri yabancı dil bilen memurlar yetiștirip, ülkelerinin eğitim programlarında Türkçe gibi Şark dillerini okuturlarken Osmanlı Devleti tercümanlık kurumu başta olmak üzere yabancı dil bilgisi gerektiren memuriyetleri Rum-Ortodokslara emanet etmişti. Divan-1 Hümayun Tercümanları'nın birçok kez Fransız, Rus kliklerine ayrılmalarına ve onlarla işbirliği etmelerine rağmen bu konuda önemli bir adım atılamamıştır. Ancak 1821'de Rum isyanı ile Rumlar görevlerinden uzaklaştırılmış ve tercümanlıklara Türkler getirilmeye başlanmıştır. Bu durumda Osmanlılar niçin bu tarihe kadar bu memuriyetleri üzerlerine almamışlardır? Ya da niçin dil bilenler bu görevlere getirilmemiştir? Osmanlılarda dil bilenler yok muydu? Osmanlılar niçin yabancı dil öğrenmemişlerdir? Osmanlıların yabancı dil öğrenmeme sebepleri arasında, Osmanlıların üstünlük duygularına kapılmaları, Batı ile ticaretin azlı̆̆ , içe kapalılık, kendi kendine yetme ve dini-ideolojik gerginlik gibi nedenler sayılabilir.

Osmanlıların üstünlük duygusuna kapılarak kendi sistemlerinin dünyadaki öbür sistemlerden daha üstün olduğuna inanmaları Osmanlı devlet adamlarında Avrupa devletlerini “aşağı görme telakkisi”ni yaratmıştır. ${ }^{8}$ Osmanlıların uluslararası sistem içindeki gücüne ve üstünlüğüne dayanarak Batı'nın görüş ve düşüncelerini öğrenmek gibi bir kaygısı olmamıştır. Osmanlıların bu üstünlük duygusu İslâmî bir temelle de desteklenmiştir. İslâm hukukuna göre dünyanın "darül-harp" ve "darülİslâm" olarak algılanması da Osmanlı ile Batı arasında kesin çizgiler çekmiştir. Hristiyanlık ile İslâmiyet'in Akdeniz ve çevresinde, savaşta ve barışta defalarca temaslarına rağmen, Rönesans ve Reform hareketleri Müslüman milletleri arasında hiçbir karşılık bulmamıştır. Hümanizm, akıl çağı, ticari devrim, sanayi devrimi, tarım devrimi Osmanlı' ya yansımamıştır. Üstünlük duygusu kısmen İslâm dünyasının dışında olup bitenleri küçümsemeyi de beraberinde getirmiştir. Bu küçümsemenin kaynağı da geleneksel anlayış ve uygulamalar oluşturmuştur.

Osmanlının hemen yanı başında bulunan Batı'yla bağlarını kesmesi ve içine kapanması yaratıcılığını yitirmesine neden olmuştur. ${ }^{9}$ Fakat burada Osmanlıların Peygamber' in "kâfirlere karşı onların silahlarıyla savaşmanın

\footnotetext{
${ }^{8}$ Karal, a.g.e., s. 73; V. Carter Findley, Kalemiyeden Mülkiyeye Osmanlı Memurlarının Toplumsal Tarihi, (çev. Gül Çağalı Güven), İstanbul 1996, s. 20; Albert Howe Lyber, Kanuni Sultan Süleyman Döneminde Osmanlı İmparatorluğu'nun Yönetimi, (çev. Seçkin C1lızoğlu), İstanbul 2000, s. 68.

${ }^{9}$ Hilmi Ziya Ülken, Uyanış Devirlerinde Tercümenin Rolü, İstanbul 1935, s. 337; Ahmet Güner Sayar, Osmanlı İktisat Düşüncesinin Çağdaşlaşması, 2. baskı, İstanbul 2000, s. 98.
} 
mübâh" olduğunu bildiren sözlerine dayanarak savaş zamanlarında Avrupa' ya özgü uygulamaları benimsediklerini de belirtelim.

Türkler Asya'dan Ortadoğu'ya gelip burada bin yıl boyunca hâkimiyet kurmalarıyla Arapça ve Farsça yanında üçüncü bir "ana İslâmî dil"10 oluşturmuşlardır. Daha önce değişik bir alfabe kullanmış olan Türkler, artık Arap alfabesi ile yazılan ve Arapça ile Farsça'dan oldukça çok kelime devşirilmiş olan yeni bir Müslüman Türkçesi ortaya çıkarmışlardır. Eğitim görmüş tüm Osmanlı yönetici/aydınların temel formasyonu Arapça ve Farsça olmuştur. Kültürlü bir Osmanlı efendisi için yabancı dil bilmek şart olmakla birlikte ve geçerli diller Arapça ve Farsça'dır. İleri düzeyde bir Osmanlı aydını/yazarı/tarihçisi olan Gelibolulu Mustafa Ali'nin Osmanlıların yükselme devrinde konu ile ilgili şu sözleri oldukça ilginçtir: "Faraza lisan-ı Arabî tekemmülü farz veya vacip olsa ve Farisi istimali sünnet-i seniyye makamında kıyam bulsa lisan-ı Türk̂̀ telaffuzu müstehab..."

Osmanlıların yabancı dil öğrenememelerinin altında yatan sebep dini gerekçeler olmadığı halde, dine, dini taassuba dayandırılmıştır. Hemen hemen bütün araştırmalar bu yöndedir. Aslında bunun kaynağı İslâm hukukunda bir Müslüman'ın, "diyar-ı küfr" olan Hristiyan memleketlerinde uzun süre oturmalarının hoş karşılanmamasıydı. ${ }^{12}$ Dolayısıyla bu durum yabancı dil öğrenimine de yansımıştır. Bu açıdan dinsel bağlamda bir Batı dilinin ve yazı sisteminin öğrenilmesi Müslümanları dinden çıkarma tehlikesini de beraberinde getirmiştir. Böylece İslâmi gelenek Osmanlı'nın Batı'yı kendisine uyarlama çabasına ket vurmuştur. ${ }^{13}$

Osmanlılarda yabancı dil meselesi üzerinde yapılan yorumlardan biri de "bir milleti taklit eden onlardan biri olur" anlayışının Batılı uygulamaları taklit etmek ve bununda bizatihi küfre ve İslâm'a ihanet olarak anlaşılmasıdır. ${ }^{14}$ Hatta büyük Şeyhülislâmlardan Ebussuud Efendi’nin şu iki fetvası bu konuda oldukça açıktır. "Mesele: Padişah-ı âlem-penâh hazretleri bir diyarı feth ettikte bazı Müslümanlar ol diyarda mütemekkin olup, ol diyarın dilince tekellüm eyleseler şer'an nesne lazım olur mu? El-cevap: Gayet muztar olup ehl-i İslâm'a dini tefhime kadir olmayıp mühim olan

\footnotetext{
${ }^{10}$ Lewis, a.g.e., s. 80 .

${ }^{11}$ Gelibolu Mustafa Ali, Künhü'l-Ahbar, c.1, s. 11'den aktaran Cornell H. Fleischer, Tarihçi Mustafa Ali Bir Osmanlı Aydın ve Bürokratı, (çev. Ayla Ortaç), 2. baskı, İstanbul 2001, s. 21 .

12 "ehl-i İslâm'ın memâlik-i Nasara'da tûl-i müddet ikametleri uyamayub", BOA, Hatt-ı Hümâyûn, No: 13745; Kuran, a.g.e., s. 1; Bernard Lewis, İslâm Dünyasında Yahudiler, (çev. Bahadır Sina Şener), Ankara 1996, s. 38.

13 Fatma Müge Göçek, Burjuvazinin Yükselişi İmparatorluğun Çöküşü Osmanlı Batılaşması ve Toplumsal Değişme, (çev. İbrahim Yıldız), Ankara 1999, s. 34-35.

${ }^{14}$ Göçek, a.g.e., s. 48.
} 
maslahatı ilâm edince ruhsat vardır. Soru: Müslim kâfir dilince zaruretsiz tekellüm eylese, nikâhına zarar olur mu? Cevap: Zararı mahzdır. Küfrüne hükme olunup avreti tefrik olunmaz." ${ }^{15}$ Görüldüğü üzere devletin en güçlü devrinde yapılan bu yorumun, yabancı dile karşı takınılan bu olumsuz tavrın sebebi aşırı güven ve Batı'yı küçümseme zihniyeti ile açıklanabilir.

Yine XVII. yüzyılın ikinci yarısında bir Fransız soylusuna esir düşen Süleyman adındaki Mısırlı bir yeniçeri, geri dönüşünden sonra kaleme aldığı eserinde Hristiyanlara yakınlık beslemekle suçlanacağını düşünerek deneyimlerini dile getirmekten çekindiğini anlatmaktadır. ${ }^{16}$ III. Selim devrinde Osmanlı Devleti'nin modernleșmesi sürerken Vak'anüvis Asım Efendi'nin Fransızca öğrenenleri "bazı kısa akıllılar"17 olarak nitelendirmesi Osmanlı aydınlarının meseleye bakış tarzını göstermektedir. Yabancı dil öğrenme meselesi hakkında Tanzimat devrinde büyük adımlar atılmış olmasına rağmen hâlâ "ecnebi bir lisan okumak ulemaya menafi görülmekte olduğundan" Ahmet Cevdet Paşa gizli gizli Fransızca çalışırdı. ${ }^{18}$ Yine Sadrazam Said Paşa, Fransızca öğrenmeye çalıştığı sıralarda, Ayasofya Camii'nde ders dinlerken Fransızca Elifba'sını düşürmesiyle arkadaşlarından birinin "aman koynuna sok, arkadaşlar görürse dayak atar" demesi bu taassubu açıkça gözler önüne sermektedir.

Hâlbuki Hz. Muhammet, Yahudilerle yapılan antlaşmalar ya da onlar tarafından gönderilen mektupların İbranice veya Süryanice yazılmış olmasından dolayı kâtibi Zeyd b. Sabit'ten İbranice ve Süryanice öğrenmesini istemiştir. ${ }^{19} \mathrm{Bu}$ durumda yabancı dil öğrenmeme alışkanlığı İslâm dini anlayışından çok dini taassubun bir sonucu olarak gözükmektedir.

Ortaylı, Osmanlıların yabancı dil öğrenememelerinin sebebini sadece üstünlük ve gururla açıklanamayacağını, bunda birazda Osmanlı tüccar gruplarının uluslararası ticarette yaygın olarak faaliyet gösterememesi olarak yorumlamışırı. ${ }^{20}$

${ }^{15}$ Mehmet Ertuğrul Düzdağ, Şeyhülislâm Ebussuud Efendi Fetvaları Ișı̆ı̆ında 16. Asır Türk Hayatı, İstanbul 1972, s. 118.

${ }^{16}$ Suraiya Faroqhi, Osmanlı Kültürü ve Gündelik Yaşam, (çev. Elif Kılıç), 4. baskı, İstanbul 2002, s. 99.

${ }^{17}$ Köprülü, M. Fuad, “Asım Efendi”,İA, c.1, İstanbul 1995, s. 670.

${ }^{18}$ Fatma Aliye, Ahmet Cevdet Paşa ve Zamanı, Kanaat Matbaası, Dersa'adet 1332, s. 34 (eserin yeni harflerle baskısı Metin Hasırcı tarafından yapılmıştır. İstanbul 1994).

${ }^{19}$ Osman Güner, Resulullah'ın Ehl-i Kitapla Münasebetleri, Ankara 1997, s. 310; Abidin Sönmez, Resülullah'm Diplomatik Münasebetleri, İstanbul 1984, s. 34 vd; Fahreddin Atar, İslâm Adliye Teşkilatı, Ankara 1979, s. 146.

${ }^{20}$ İlber Ortaylı, "Osmanlı Diplomasisi ve Diş İşleri Örgütü”, Tanzimattan Cumhuriyete Türkiye Ansiklopedisi, c. 1, s. 278; Sayıları azda olsa yurt dışında faaliyet gösteren Osmanlı ticaret grupları için bkz. Bernard Lewis, Çatışan Kültürler, Keşifler Çağında Hristiyanlar, Yahudiler, Müslümanlar, (çev. Nurettin Elhüseyni), İstanbul 1997, s. 18; Şerafettin Turan, "Venedik'te Türk Ticaret Merkezi, Fondaco dei Turchi”, Belleten, 126/Nisan 1968, s. 247- 
İslâm dünyasının Batı dillerine karşı gösterdiği duyarsızlık sadece Osmanlılarla sınırlı kalmamıştır. Endülüs'te bile bu ilgisizlik mevcuttur. ${ }^{21}$

Osmanlılar gayrimüslim dilleri öğrenmeyi reddetmiş olmalarına rağmen sayısı azda olsa Batılı dillerde yazılmış eserlere başvurmuşlardır. Fakat batılı kaynaklara başvuranların sayıca az olmaları ve etraflarında eğitilebilecek bir grubun olmaması ayrıca bir talihsizliktir. 1640 yılına kadar hiçbir Osmanlı tarihçisi batılı yazarların Osmanlı Devleti üzerine neler kaydettiklerini dikkate almamıştı. İlk kez İbrahim Peçevi (1574-1650) bu konuda Macar tarihçilerine başvurmuştur. ${ }^{22}$

Yine Peçevî gibi XVI. yüzyılın seçkin okumuşlarından Feridun Bey, Hasan b. Hamza ve Ali b. Sinan'a bir Fransa tarihi tercüme ettirmiştir. ${ }^{23}$ XVII. yüzyılın sonunda Latince, Yunanca, Fransizca bilgisiyle Hezarfen Hüseyin Efendi Batı kaynaklarından yararlanmış Tenkihü’t-Tevarih-i Mülûk adlı dünya tarihinin Yunan, Roma, Bizans'la ilgili kısımlarını Yunanca ve Latince den çevirttirmiş, çağdaşı olan Kont Marsigli, Dimitri Cantemir, Galland gibi Avrupalı âlimlerle görüşmüş, fikir alışverişinde bulunmuştur. ${ }^{24}$

Batılı eserlerden faydalanan Osmanlı aydınları arasında Kâtip Çelebi de anılmalıdır. Kâtip Çelebi, Düstûrü'l-Amel'e zeyl olarak kaleme aldığg İrşâdü'l-Hayara ila Tarihi'l-Yunan ve'n-Nasara adlı küçük eserinde Hristiyan Avrupa'nın gittikçe kuvvet kazanmasına karşın, İslâm tarihçilerinin bu âlemi boş ve yanlış sözlerle tasvir etmesine üzülerek din kardeşlerini, "gafletten uyandırmak" için bu kitabı yazdığını belirtmiştir. ${ }^{25}$ Kâtip Çelebi'nin Avrupa tarih ve coğrafyasıyla uğraşması onu Avrupa kaynaklarını incelemeye sevk etmiş ve Fransız rahibi iken Müslüman olan İhlasî Mehmed Efendi de kendisine yardımcı olmuştur. ${ }^{26}$

Osmanlı Devleti, diplomatik ilişkilerin "vazgeçilmezi" olan Divan-1 Hümâyûn ve Donanma Tercümanlıkları'nı Rum Ortodoks Fenerli Beylere bırakmıştı. Fakat zaman zaman bu tercümanların sadakatlerinden emin

275; Fransa'da faaliyet gösteren bir Osmanlı ticaret grubu için bkz. Halil İnalcık, Doğu Batı, Makaleler I, 2. bask1, Ankara 2005,s. 298-299.

${ }^{21}$ Lewis, Müslümanların Avrupa'yı Keşfi, s. 82.

${ }^{22}$ Sayar, a.g.e., s. 99; Bernard Lewis, Modern Türkiye'nin Doğuşu, (çev. Metin Kıratlı), 8. Bask1, Ankara 2000 s. 53.

23 Jean Louis Bacque-Grammont, "Feridun Bey'in Az Bilinen Bir Yapıtı "Tevarih-i Padişahan-1 Françe” Üzerine Bazı Düşünceler”, XII. Türk Tarih Kongresi, Ankara 12-16 Eylül 1994, Kongreye Sunulan Bildiriler, (çev. Aksel Tibet), c. 4, Ankara 1999, s. 1398.

${ }^{24}$ Hezarfen Hüseyin Efendi, Telhisü'l-Beyân fi Kavanîn-i Âl-i Osman, (haz. Sevim İlgürel), Ankara 1998, s. 5,6,8; İlber Ortaylı, İmparatorluğun En Uzun Yüzyılı, 3. baskı, İstanbul 1995, s. 11, Faroqhi, a.g.e., s. 219.

${ }^{25}$ Bekir Kütükoğlu, Vekayinüvis, Makaleler, İstanbul 1994, s. 32-33; Adnan Adıvar, Osmanlı Türklerinde İlim, İstanbul 1970, s. 126.

${ }^{26}$ Mehmed İhlasi hakkında bkz. Adıvar, a.g.e., s.126, n. 3; Fikret Sarıcaoğlu, "Şeyh Mehmet İhlasi”, Türkiye Diyanet Vakfı İslam Ansiklopedisi, c. 21, s. 538-539. 
olunamıyordu. İmparatorluk eğitim sisteminde de yabancı dil okutulmadığı için bu tercümanlara mecbur kalınıyordu.

Bu durum 1821'de açılmış olan Babıâli Tercüme Odası'na kadar sürmüştür. Babıâli Tercüme Odası'nın açılmasıyla tespit edebildiğimiz ilk nizamnamesi 17 Aralık 1824'te yapılmıştır. İlk defa Lisan Mektebi denemesi bu tarihte yapılmıştır. Buna göre Babıâli Tercüme Odası ilk kuruluş yıllarında biri Beylikçi Efendi'nin nezaretinde dil öğrenecek memurların devam ettiği Lisan Odası ve diğeri de buradan mezun olup tercüme işleriyle meşgul olacak mütercimlerin çalıştı̆̆ 1 Tercüman Odası olmak üzere iki birimden oluşmaktaydı. Lisan Odası'nda dil öğrenen memurlar, mütercim olarak Tercüman Odası'na alınır ve burada eksikliklerini tamamlarlardı. Bu mütercimler Tercüman Odası'nda tercümeleri "tebyiz" ve ceridelere kayd etmek ve boş kaldıklarında birbirleriyle Fransızca konuşup dil bilgilerini ilerletmek zorundaydılar. Tercüman Odası'nda çalışan memur bir başka göreve atandığı zaman yerine Lisan Odası'ndan diğeri atanacak ve böylece Tercüman Odası bağımsız bir birim haline getirilecektir. Tercüman Odası'nda tercüme edilen evrakın eskisi gibi kaybolmayarak kaydı tutulacak, evrakın müsvedde ve asılları torbalarda muhafaza edilecekti. Tercüman Odası mensuplarına ait olan maaşlar da kişilere değil memuriyetlerine ait olacaktı. Tercüme Odası'nda çalışan mütercimler izinsiz olarak göreve gelmediklerinde ya da tercüme ve tekellüme "ez can-l dil" çalışmadıkları zaman Oda'dan atılacak ve yerine Lisan Odası'ndan diğeri atanacaktı. ${ }^{27}$

Tercüme Odası'nın çalışmaları Başhoca İshak Efendi ve Zenob'un idaresi altında 1824'teki yenilikler doğrultusunda beş yıl daha devam etmiștir. Yahya Naci Efendi ile birlikte hepsi Mühendishane kökenli olan bu tercümanları Findley "marjinal kimseler" olarak nitelendirmiștir. ${ }^{28}$ Bununla beraber Zenob'un idaresi altında bulunan "Lisan Odası" vasıflı tercümanlar yetiştirmek bakımından pek başarılı olamamıştır. Lisan Odası'nda 500 kuruş maaşla ders veren Ermeni Zenob'un derslerini takip edenlerin "şimdiye kadar tekellüme muktedir olamayıp bir semere hâsıl olamamış" olması, Zenob'un "Katolik habislerinden" olması ve "bedhah gürûhundan" bulunmasıyla Zenob'un Babıâli'ye gelip gitmesinin mahsurlu olacağ 1 düşünülerek görevinden alınmış ve İstanbul'dan sürülmesine karar verilmiştir. Yine aynı belgede Tophane-i Amire'de de Fransızca

27 Tercüme Odası hakkında ayrıntılı bilgi için bkz. Sezai Balcı, Osmanlı Devleti'nde Tercümanlık ve Babıali Tercüme Odası, Ankara Üniversitesi, Sosyal Bilimler Enstitüsü, Yayınlanmamış Doktora Tezi, Ankara 2007; BOA, Mühimme Defteri, No: 241, hüküm, 1811, s. 392, 25 Ra 1240/17 Kasım 1824; Ali Akyıldız, Osmanlı Merkez Teşkilatında Reform (1836-1856), İstanbul 1993, s.74-75.

${ }^{28}$ Carter V. Findley, Osmanlı Devletinde Bürokratik Reform Babıâli (1789-1922), (çev. Latif Boyacı-İzzet Akyol), İstanbul 1994, s.114. 
öğretilmekte olduğundan bahsedilerek Lisan Odası'nın gereksiz olduğuna karar verilmiştir. ${ }^{29}$

\section{Lisan Mektebi'nin Açılması}

Bugün İstanbul Cağaloğlu Moda Tasarımı Anadolu Meslek Lisesi olarak kullanılan Lisan Mektebi hakkında bugüne kadar müstakil bir çalışma yapılmamıştır. Sadece Osman Nuri Ergin'in Türkiye Maarif Tarihi adlı eserinin ikinci ve üçüncü ciltlerinde kısmen bahsedilmekle beraber önemli bilgilerde verilmiştir. ${ }^{30}$ Ergin'in bu çalışmasından sonra Faik Reşit Unat, Türkiye Eğitim Sisteminin Gelişmesine Tarihi Bir Bakış adlı eserinde Lisan Mektebi'nden bahsetmiş fakat konuya herhangi bir yenilik getirmemiştir. ${ }^{31}$ Konuyla ilgili olarak üçüncü bir çalışma da Cavide Işıksal'ın "Türkiye'de Açılan İlk Yabancı Dil Okulları" adlı makalesindeki iki arşiv belgesinin transkripsiyonudur. ${ }^{32}$

Babıâli Tercüme Odası'nın zamanla, Osmanlı Devleti'nin idari teşkilatında yabancı dil öğretilen bir okul olma misyonunu yitirmesiyle Lisan Mektebi'nin açılması gündeme gelmiştir.

Lisan Mektebi'nin açılması hakkında ilk teşebbüsü Maarif-i Umumiye Nazırı Kemal Efendi yapmıştır. 3 Mart 1866 tarihli tezkeresinde Kemal Efendi, rüşdiye mekteplerinde Arapça ve Farsça'nın okutulduğunu Fransızca öğrenmek isteyen bazı öğrencilerin Galata ve Beyoğlu'nda bulunan yabancı okullara gittiklerinden bahsederek "bazı muamelatça görülen lüzum üzerine" Lisan Mektebi'nin açılmasının zaruretini dile getirmiştir. Kemal Efendi ayrica bu okulun Hariciye Nezareti kalemlerine girecek olan memurlara da

${ }^{29}$ BOA, Hatt-ı Hümâyûn, No: 24621; Akyıldız, a.g.e., s.75; Carter V. Findley, "The Foundation of the Ottoman Foreign Ministry", International Journal of Middle East Studies, 3/1972, s. 403. Findley, İngiliz elçisine dayanarak Zenob'un birkaç dili hayranlık uyandıracak derecede iyi konuştuğunu belirtiyor, Findley, a.g.m., s.401; Tercüme Odası'ndan tard edilen Zenob daha sonra Viyana Sefareti Tercümanı iken devlet hizmetini bırakmıştır. BOA, Hatt-ı Hümayun, No: 34965 A, (24 Za 1254/8 Subat 1839) (Burada Zenob'un (1215/1801)'den beri devlet hizmetinde bulunduğu, Donanma'da Tercümanlık yaptığından vb. bahsediliyor). Zenop'un Mühendishanede'ki görevi için bkz. Kemal Beydilli, Türk Bilim ve Matbaacılık Tarihinde Mühendishane, Mühendishane Matbaası ve Kütüphanesi (1776-1826), İstanbul 1995, s.312-318; Uluçay-Kartekin, Yüksek Mühendis Okulu, s.69,498-499; Zenob ve Ailesi hakkında bkz. Kevork Pamukciyan, "Manas Ailesi”, Dünden Bugüne İstanbul Ansiklopedisi, c.5, İstanbul 1994, s. 286-287; Y. G. Çark, Türk Devleti Hizmetinde Ermeniler, İstanbul 1953, s.142-143; Zenob'a (1260/1844)'de verilen muafiyet beratı için bkz. BOA, Cevdet Maliye, No: 21602, (Cemaziyelahir 1260/18 Haziran-16 Temmuz 1844).

${ }^{30}$ Osman Nuri Ergin, İstanbul Mektepleri ve İlim Terbiye ve Sanat Müesseseleridolayısıyla-Türkiye Maarif Tarihi, c. 2-3, İstanbul 1940-1941, s. 533-542 ve s. 1046-1052.

${ }^{31}$ Faik Reşit Unat, Türkiye Eğitim Sisteminin Gelişmesine Tarihi Bir Bakış, Ankara 1964, s.71, 75.

32 Cavide Işıksal, “Türkiye'de Açılan İlk Yabancı Dil Okulları”, Belgelerle Türk Tarihi Dergisi, VII/May1s 1968, s.29-31. 
faydalı olacağı görüşündedir. ${ }^{33}$ Böylece okulun açılması için ilk adımlar atılmıştır. Okul başlangıçta Mahrec-i Aklâm Mektebi'nin içinde açılmış ve okulun ilk öğrencileri de Mahrec-i Aklâm ve Darü'l-Maarif mektepleri mezunlarından sınavla seçilen 20 kişilik bir grup olmuştur. Ayrıca okulun yıllık bütçesi de 25 bin kuruş olarak öngörülmüştür. Maarif-i Umumiye Nazırı Kemal Efendi'nin bu tezkeresine 26 Mart 1866'da verilen onayla ${ }^{34}$ Lisan Mektebi, 20 kadar öğrenci ile birlikte eğitim hayatına başlamıştır.

Bu ilk dönemde Lisan Mektebi'nin dersleri ve hocaları hakkında çok fazla bilgiye sahip olmamakla birlikte okulda sadece Fransızca öğretildiğini biliyoruz. 24 Haziran 1867'de Maarif ve Maliye nezaretlerine yazılan bir yazıda okulun ikinci yılında mektebe 15 öğrenci daha alınacağından bahsedilerek okulun 25 bin kuruş olan tahsisatı da 40 bin kuruşa çıkarılmıştır. Yine aynı tarihte yapılan bir düzenleme ile okula devam eden ve devamsızlık yapmayan öğrencilere istedikleri kalemlere memur olmaları usulü de getirilmiştir. ${ }^{35} \mathrm{Bu}$ uygulamayla öğrencilerin verimliliklerinin arttırılacağı düşünülmüştür. $\mathrm{Bu}$ amaçla öğrencilere "varaka-i müşsevvike" olmak üzere birer kıt'a rü'ûs-1 hümâyûn verilmesi de kararlaștırılmıș ve 29 Haziran 1867 'de 12 öğrenciye rü'ûs verilmiştir. ${ }^{36} \mathrm{Bu}$ tarihte okulun Fransızca öğretmeni olarak sadece Adosidi Efendi'nin adı geçmektedir. ${ }^{37}$

Lisan Mektebi ilk başlarda sadece Fransızca öğretimi için açılmışsa da Osmanlı bürokrasisinin pratik ihtiyaçları için okula yeni dersler de ilave edilmiştir. Özellikle Düstûr'un Rumca, Bulgarca ve Ermenice'ye çevrilmesi gerektiğinden o sırada Maarif Nazırı bulunan Subhi Efendi, Rumca ve Bulgarca sınıflarının açılmasını istemiştir. ${ }^{38}$ Subhi Efendi'nin bu önerisi

\footnotetext{
${ }^{33}$ BOA, İrade Dahiliye, 38078, 3 Mart 1866/29 Şevval 1282 tarihli Kemal Efendi'nin tezkeresi.

${ }^{34}$ BOA, İrade Dahiliye, 38078, 9 Zilkade 1282/26 Mart 1866; BOA, Sadaret Mektûbî Mühimme (A. MKT. MHM.), 352/35, 12 Zilkade 1282/29 Mart 1866; 26 Mart 1866'da açılan Lisan Mektebi'nin açılma tarihini Ergin, 18 Eylül 1283 tarihli bir belgeye göre 1864 olarak kabul etmiş̧ir. Oysa bu Rumi tarihin miladi karşılığı 30 Eylül 1867'dir. Ergin, a.g.e.,c. 2, s. 534 ve c. 3, s. 1046; Ergin'den sonra diğer araştırmacılar da çalışmalarında 1864 tarihini vermişlerdir. 1864 tarihi için bkz. Işıksal, a.g.m., s. 30; Necdet Sakaoğlu, Osmanlı'dan Günümüze Eğitim Tarihi, İstanbul 2002, s. 79; Karal, a.g.e., c. 7, s. 204; Unat, a.g.e., s.72; Erdal Ceyhan Türk Eğitim Tarihi Kronolojisi, Edirne 2004, s. 22.

35 BOA, Sadaret Mektûbî Mühimme, 385/70, 24 Haziran 1877/21 Safer 1284, belgede geçen "ikinci yıl" ifadesi de okulun 1866'da açıldığını teyid etmektedir.

${ }^{36}$ BOA, Sadaret Mektûbî Mühimme, 386/60, 29 Haziran 1867/27 Safer 1284; Rü'ûs devlet memurlarının tayin işlemlerini gösteren belgedir. Başbakanlık Osmanlı Arşivi Rehberi, 2. bask1, İstanbul 2000, s .72.

371284 (1867) Sâlnâme-i Devlet-i Aliyye-i Osmaniye, Darüt-Tıbaatil Amire Matbaası, İstanbul 1284 (1867), s. 82.

38 Maarif Nazırı Subhi Efendi tezkeresinde Düstur'un Rumca'ya tercümesi için Kostaki Antabolu Efendi'nin görevlendirildiğini ve Bulgarcası için bir adam bulunamadığını söyleyerek bu lisanlara vakıf memurlar yetiştirilip Rum ve Bulgar lisanı ile konuşulan
} 
Meclis-i Vâlâ' da görüşülerek Lisan Mektebi'ne bir Rumca sınıfının açılması kararlaştırılmış ve Rumca sınıfının öğretmenliğine 5 Aralık 1867'de 700 kuruş maaşla İstatistik Kalemi Mütercimi Kostaki Efendi atanmıştır. Meclisi Vâlâ'ca öğrencilerin eğitimlerini aksatmaması ve verimliliğin düşmemesi için açılacak olan Rumca sınıfının Fransızca sınıfından ayrı tutulmasına da karar verilmiştir. ${ }^{39} 7$ Kasım 1867'de Bulgarca sınıfı öğretmenliğine Mekteb-i Tibbiye öğrencilerinden Dimitri Efendi 400 kuruş maaşla atanmıştı ${ }^{40}$. Rumca ve Bulgarca öğretmenlerinin atanmasından sonra 19 Ocak 1869'da 1200 kuruş maaşla Fransız Dö Mantran Roj, İnşa muallimliğine atanmıştır. ${ }^{41}$ Lisan Mektebi'nin öğrenci sayısını ve öğretmen kadrosunu sâlnâmelerden takip etmek mümkündür. 1286 (1869) Devlet Sâlnâmesi'ne göre okulun öğrenci sayısı 66, Müdürü Cemal Bey, Mektep Müfettişi Dolis, birinci sınıf muallimi Adosidi, ikinci sınıf muallimi Berdu Motnat Roj, üçüncü sınıf muallimi Osman Efendi'dir. ${ }^{42} \mathrm{Bu}$ öğretmen kadrosuna 1870'de Baron, İstimtaki ve Gatban Efendiler de eklenmişlerdir. ${ }^{43} 4$ Eylül 1867 'de yani okulun açılmasından iki sene sonra Lisan Mektebi'nin tamir ve mefruşatına 7746 kuruşun harcanması okula verilen önemin bir göstergesidir. ${ }^{44}$

İlk defa açılan Lisan Mektebi ile ilgili olarak bilgilerimiz bununla sınırlıdır. Okulun ne zaman kapatıldığını bilmiyoruz. Arşivde yaptığımız araştırmalarda ve konu ile ilgili eserlerde herhangi bir bilgiye ulaşamadık.

\section{Lisan Mektebi'nin İkinci Defa Açılması}

Lisan Mektebi'nin 1879'da yeniden açılması Ahmed Arifi Paşa'nın tezkeresi üzerine olmuştur. 24 Eylül 1879'da Sadrazam Ahmed Arifi Paşa

memleketlerde istihdam edilmelerinin öneminden bahsediyor. BOA, İrade Meclis-i Vâlâ, 26127, 2 Cemaziyelahir 1284/ 30 Eylül 1867.

${ }^{39}$ BOA, İrade Meclis-i Vâlâ, 26127, 9 Şaban 1284/5 Aralık 1867 "Fransızca okutturulacak şakirdan diğer elsine ile meşgul ettirilmeyecek onlar için başka sınıf tertibi”; BOA, Sadaret Mektûbî Mühimme , 395/94, 13 Şaban 1284/8 Aralık 1867.

40 BOA, İrade Dahiliye, 39585, 11 Receb 1284/7 Kasım 1867; 1285 (1868) Devlet Sâlnâmesi'nden de okulun Fransızca Öğretmeni Adosidi Efendi, Rumca Öğretmeni Kostaki, Bulgarca Öğretmeni olarak Dimitri Efendi'nin ismi geçmektedir, 1285 (1868) Sâlnâme-i Devlet-i Aliyye-i Osmaniye, Darüt-Tıbaatil Amire Matbaası, İstanbul 1285 (1868), s. 92.

${ }^{41}$ BOA, Sadaret Mektûbî Mühimme , 431/100, 5 Şevval 1285/ 19 Ocak 1869.

421286 (1869) Sâlnâme-i Devlet-i Aliyye, İstanbul 1286 (1869), Darüt-Tibaatil Amire Matbaası, s. 109.

1287 (1870) Sâlnâme-i Devlet-i Aliyye, İstanbul 1287 (1870), Darüt-Tıbaatil Amire Matbaası, s. 118.

${ }^{44}$ BOA, Sadaret Mektûbî Mühimme, 419/25, 16 Cemaziyelevvel 1285/4 Eylül 1867, Yusuf Ziya ve Naşid mühürlü. Bu belgeye okula alınan malzemeler perde, kitap bezi, perdelere kordon, hasır, halı, kese, kanepe, sıra ve hokka'dan oluşmaktadır. Belgeye göre bu tarihte Lisan Mektebi, üç ders yapılan sınıf, iki küçük oda, bir teneffüs odası, bir müdür odası ve bir sofadan oluşmaktadır.;Yine Lisan Mektebi, Mahrec-i Aklâm, Darülmuallimin, Mülkiye ve Bayezid Rüşdiyeleri için alınan sobalara 3730 kuruş ödenmiştir. BOA, Sadaret Mektûbî Mühimme , 434/29, 25 Şevval 1285/8 Şubat 1869. 
tezkeresinde devlet idaresi için bir "Elsine Mektebi”nin açılması gerektiğini, okulun öğretmen, öğrenci, hademeleri ve diğer masrafları için ilk dört yılında her ay 8150 kuruş para ayrılacağını ve dört sene sonra bu miktarın aylık 27.900 kuruşa çıkacağını, Şura-yı Devlet Tanzimat Dairesi'nce 1 Mart 1879 'da hazırlanan altı maddelik nizamnamesinin kabul edildiğini ve bu dil okulunun açılması sırasında kaldırılması düşünülen eğitim kurumlarının 1slah edilerek kaldırılmaktan vazgeçildiğini belirterek durumu Padişah II. Abdülhamit'e arz etmiş ve II. Abdülhamit de bu okulun programına Fransızca gibi Arapça'yı da mecbur tutarak onaylamıştır. Okulun altı maddelik nizamnamesine göre okulun öğrenim süresi dört yıl olacaktı. Arapça ve Fransızca ile inşa dersleri mecburi tutulmasının yanı sıra Rumca, Slavca, Ermenice, İngilizce, Almanca ve Rusça da programa dâhil edilmiştir. $\mathrm{Bu}$ dillerden Arapça ve Fransızca yanında her ögrencinin Rumca ve Ermenice'yi de öğrenmeleri mecbur tutulmuş, diğer dillerin öğrenimi ise öğrencilerin isteğine bağlı olması kararlaştırılmıştır. Okula öğrenci alınırken "mekâtib-i resmiyeyi" bitirenler diplomalarıyla ve bitirmeyenler de sinavla alınacaklardı. Yine Lisan Mektebi'ni bitiren öğrenciler, sefaret maiyet memurlukları, çeşitli nezaretlerin Tercüme odaları, şehbenderlikler, demiryolları idaresi, vilâyet tercümanlıkları gibi devletin ihtiyaç duyduğu ve yabancı dil bilgisi gerektiren memuriyetlerde istihdam olunacaklardı. ${ }^{45}$

$\mathrm{Bu}$ nizamnameye göre Lisan Mektebi'nin programına Arapça ve Farsça'nın konulmasını, yani neredeyse bin yıldır bir metod içinde öğretilememiş olan bu iki dilin artık Fransızca gibi öğretilmeye çalışılmasını Ergin haklı olarak eleştirmektedir. ${ }^{46}$

\section{Lisan Mektebi'nin Üçüncü Kez Açılması}

8 Ekim 1883 tarihli bir belgede yeni bir Lisan Mektebi'nin açılmasından bahsedildiğine göre önceki okul kapatılmış olmalıdır. Yeni Lisan Mektebi de daha öncekiler gibi devletin pratik ihtiyaçlarına cevap vermek amacıyla açılmıştır. Açılış gerekçesinde Babıâli Tercüme Odası'nda bulunan mütercimlerin azalması ve bu yüzden birçok evrakın gecikmesi, Tahrirat-1 Hariciye Odası'nın yetersiz kalması, Fransızca bilen memurların da kalemlerinden başka görevlere atanarak yabancı dil bilen Hariciye Nezareti personelinin sayısının azalması gibi nedenlere yer verilmiştir. Bu

\footnotetext{
45 Ahmed Arifi Paşa'nın tezkereyi kaleme alışı 23 Eylül 1879, onay tarihi 24 Eylül 1879'dur. Nizamnamesi Şura-yı Devlet Tanzimat Dairesi'nce 31 Mart 1879'da yapılmıştır. Işıksal, a.g.m., s.30-31, Işıksal, bu belgeyi verirken Sadrazam Said Paşa imzalı olduğunu kayd ediyor, fakat bu sırada Sadrazam Ahmed Arifi Paşa'dır. Işıksal'ın verdiği belge Ergin'de bulunmaktadır. Ergin, a.g.e., c. 3, s.1046-1051.

46 Ergin, a.g.e., c.2, s.538; Bu nizamnamede okul programına Arapça ve Farsçanın eklenmesine rağmen Hariciye sâlnâmelerinde verilen ders programlarında Arapça ve Farsça bulunmamaktadır.
} 
amaçla Lisan Mektebi'ne öncelikle Babıâli Tercüme Odası ve Mektûbî-i Hariciye Odası'nda bulunan ve yaşları 25'i geçmeyen memurların alınmaları düşünülmüştür. $\mathrm{Bu}$ kalemlerin yanı sıra diğer kalemlerden de isteyenler okula devam edebileceklerdi. Okulun eğitim süresi beş sene ve sınıf sayısı da beş olarak düşünülmüştür. Lisan Mektebi yine Hariciye Nezareti'ne bağlı olacak ve hocalarına da aylık dokuz bin kuruş maaş ödenecekti. ${ }^{47} 1303$ (1886) Devlet Sâlnâmesine göre mektep gündüzleri açik olacak ve isteyen öğrenciler parasız olarak okula devam edeceklerdi. ${ }^{48}$

Okulun yeniden açılmasıyla birlikte okulun usul-i tercüme birinci muallimliğine sadece sabahları devam etmek üzere 1200 kuruş maaşla Babıâli Tercüme Odası Müdürü Ahmed Bey, Fransızca Muallimliğine 2000 kuruş maaşla Mösyö Namziye ve sabahları sadece üç saat ders vermek üzere 1400 kuruş maaşla Pravni (Proni) ve okulun müdürlügüne de 800 kuruş maaşla Divan-1 Hümâyûn Kalemi hulefasından Nebih Efendi atanmıştır. Bunların dışında sabahtan akşama kadar ders vermek için 1600 kuruş usul-i tercüme ikinci muallimliği ve 2000 kuruş maaşla Fransızca birinci muallimliklerine de birer kadro tahsis edilmiştir. ${ }^{49}$

6 Mart 1885'te Osmanlı Devleti'nin dış ilişkilerinde önemli rol oynayan elçilik maiyetlerinde sırkâtip, ataşe, şehbender ve kançılaryada istihdam olunacak memurlar ile Hariciye Nezareti'ne yeni girecek memurların Fransizca bildiklerine dair ya Lisan Mektebi'nden ya da diğer okullardan diploma almaları kararlaştırılmıştır. ${ }^{50} \mathrm{Bu}$ sırada bütün genç memurların Lisan Mektebi'ne girmeleri ve dil öğrenmeleri için dairelerce teşvikler yapılmıştır. Böylece Lisan Mektebi'ne gösterilen özen ve titizlik kısa sürede kendini göstermiş ve okulun birinci sınıfına 160 öğrenci kaydını yaptırmıştır. Okula gösterilen bu rağbet sonucu birinci sınıf 12 Ocak 1885 tarihinde iki şubeye bölünmüş ve ikinci şube muallimliğine Babıâli Tercüme Evrak Odası Muavini Konstantin Efendi atanmıştır. ${ }^{51}$

47 "Lisan Mektebi'nin Tesisine ve Usûl-i Tedrisiyesine Dair", Düstûr, c.4, Matba'a-i Osmaniye, Dersaadet 1302, s.53-54; BOA, Ayniyât Defteri, No: 1254, s.165, 8 Zilhicce 1300/10 Ekim 1883, Hariciye ve Maliye Nezaretlerine; BOA, Ayniyât Defteri, No: 1254, s. 229, 26 Zilhicce 1300/28 Ekim 1883, Matbuat İdaresi'ne yazılan tezkere; Ergin, a.g.e., c.2, s.536-537.

481303 Sâlnâme-i Devlet-i Aliyye-i Osmaniye, Mahmud Bey Matbaası, İstanbul 1303, s. 322.

${ }^{49}$ BOA, Ayniyât Defteri, No: 1254, s. 193, Gurre Zilhicce 1300/ 3 Ekim 1883.

${ }^{50}$ Salname-i Nezaret-i Hariciye 1306, Osmanlı Dışişleri Bakanlığı Yıllığı, (yay. Haz. Ahmet Nezih Galitekin), İstanbul 2003, s. 230.

${ }^{51}$ BOA, İrade Hariciye, 18703, 25 Rebiülevvel 1302/12 Ocak 1885 Mütercim-i Evvel Davud Efendi tarafından yazılan yazı; Okulun iki adet odacı/müstahdem için aylık 600 kuruş maaş ve okulun kütüphanesinin bahçesine bakan bahçıvana da 300 kuruş maaş bağlanmıştır, BOA, Ayniyât Defteri, No: 1567, 11 Safer 1303/18 Kasım 1885, s. 235; Odaciların bu maaşları daha sonra tenzil-i maaş ile 500 kuruşa indirilmiştir. BOA, Ayniyât Defteri, No: 
Bu amaçla da Lisan Mektebi inşaatı için dört ev ile iki arsa da devlet tarafından istimlâk edilmiştir. ${ }^{52}$ Böylece yeniden düzenlenen Lisan Mektebi'nin, 5 Kasım 1883'te Cağaloğlu'nda Maarif Nezareti'nin malı olan Arif paşa arsasına 250 bin kuruş masrafla yaptırılması kararlaştırılmıştır. ${ }^{53}$ $\mathrm{Bu}$ sırada Lisan Mektebi'nin giriş kapısına Padişah II. Abdülhamid'in tuğrası ile “Heza Mektebü'l-Lisan ismü'l- Sultanü'l- Gazi-yi Abdülhamid Hanü'l-Sani Halidullah-ı Mülk ve Id-i Saltanat 1302" şeklinde tarih de düşürülmüştür. ${ }^{54}$

Bu sırada “derdest inşa olunan" Lisan Mektebi'ne ilave edilmek üzere istimlâk edilmesi gereken evlere ve arsalara ödenecek olan para Şehr Emaneti Meclisi Reisi Remzi Efendi ile İnşaat Dairesi Muavini Abid Paşa tarafından 2630 lira olarak kararlaştırılmıştır. Bu istimlâk işinin gerekçesi de okulun çevresinde bulunan evlerin okula yaklaşık bir buçuk arşın mesafede olması ve olası yangın tehlikesinden kaynaklanmıştır. ${ }^{55}$

13 Temmuz 1886'da Maarif Nazırı Saffet Paşa zamanında Lisan Mektebi inşaatına ayrılan 250 bin kuruşluk ödeneğin yetmemesi üzerine okul inşaatının bitimine kadar haftalık olarak 30 bin kuruşun Bab-1 Vâlâ-yı Seraskeri İnşaat Dairesi'ne yatırılması kararlaştırılmıştır. ${ }^{56}$

Lisan Mektebi eğitim ve öğretime devam ederken bazı öğrencilerin okula devam etmedikleri anlaşılmış ve bunların memuriyet yaptıkları ilgili dairelere uyarılarda bulunulmuştur. ${ }^{57}$ Yapılan bu uyarıların etkisi olsa gerektir ki okulun öğrenci sayısı 1303 Devlet Sâlnâmesi'ne göre 550'ye çıkmıştır. ${ }^{58}$

14 Ocak 1886'da Lisan Mektebi muallimlerinden Mösyö Proni görevini bırakmış ve yerine Mekteb-i Sultani Muallimi Mösyö Perad atanmıştır. ${ }^{59}$

1568, 2 Cemaziyelahir 1303/8 Mart 1886, s. 22-23.

52 BOA, Nezaret Gelen-Giden Defterleri, No: 396, 3 Muharrem 1301/3 Kasım 1883, sira no: 121.

${ }^{53}$ BOA, İrade Dahiliye, 71685, 5 Muharrem 1301/5 Kasım 1883.

${ }^{54}$ BOA, İrade Dahiliye, 74216, 27 Rebiülevvel 1302/ 14 Ocak 1885, 17 Rebiülevvel 1302/4 Ocak 1885 Tarihli Maarif Nezareti'nin tezkeresi üzerine.

${ }^{55}$ BOA, İrade Dahiliye, 74643, 26 R 1302/12 Şubat 1885, 19 Rebiülahir 1302/6 Ocak 1885 tarihli Maarif Nezareti tezkeresine cevaben (harik muhatırasına müstaid olub).

${ }^{56}$ BOA, Şura-yı Devlet, 209/55, 11 L 1303/ 1 Temmuz 1302, Maarif Nazırı Safvet Paşa ve Şura-yı Devlet Reisi Arifi Paşa imzalı.

${ }^{57}$ BOA, Ayniyât Defteri, No: 1567, s. 81, 1 Cemaziyelahir 1302/16 Şubat 1885 (Aralık 1885'in devam-devamsızlık raporları); BOA, Ayniyât Defteri, No: 1567, s. 93, 23 Cemaziyelahir 1302/9 Nisan 1885.

${ }^{58} 1303$ Sâlnâme-i Devlet-i Aliyye-i Osmaniye, Mahmud Bey Matbaası, İstanbul 1303, s. 322; ertesi yıl bu sayı 549'a düşmüştür. 1304 Sâlnâme-i Devlet-i Aliyye-i Osmaniye, Mahmud Bey Matbaasi, İstanbul 1304, s. 310.

${ }^{59}$ BOA, Ayniyât Defteri, No: 1567, 8 R 1303/ 2 Kanun-1 Sani 1301/ 1 Ocak 1886. 
1 Şubat 1886 ' da okulun dördüncü yılı bitmiş ve beşinci sınıfı açılmıştır. Beşinci sınıf öğretmenliğine de üçüncü ve dördüncü sınıf muallimi Pirar, dördüncü sınıf muallimliği uhdesinde kalmak üzere getirilmiştir. Bu sırada ikinci sınıfın ayrı bulunan iki şubesi birleştirilerek öğretmenliğine birinci şube öğretmeni Kostaki Efendi, ikinci şube öğretmeni Daniş Efendi de Mösyö Döbova' dan münhal kalan üçüncü sınıf muallimliğine atanmıştır. ${ }^{60}$

\section{Lisan Mektebi'nin Dersleri}

1885 'te okulun birinci sınıfında bulunan öğrenci sayısı 145, ikinci sınıfında 113, üçüncü sınıfında 30, dördüncü sınıfında 13 olmak üzere 301'dir. Lisan Mektebi'nin öğretmenleri de Usul-i Tercüme'de Ohannes Efendi ve Ahmet Bey, Usul-i Fransevî'de Pronin, Ohannes, Kostaki Dikran ve Kostantin Efendilerdir ${ }^{61}$. 1301 (1885) Hariciye Sâlnâmesine göre okulun dersleri şöyle düzenlenmiştir:

Birinci Sınıf: Tahrir, Mebâdî-i Ta'lîm-i Lisân, Tasrîf-ü Ef'âl, Teşkil-i Ezmine Cetveli, Cem'in Teşekkülü, Mükâlemât.

İkinci Sınıf: Larus'un (Larousse) Muhtasar Ta'lim-i Lisanı, Mükâleme (Me'badî), Mekâtib-i Müsta'mele, Ezber, Suret-i İbtidâiyede Dikte, Ma'lûmât-1 Tarihiyye ve Coğrafiyye.

Üçüncü Sınıf: Nahv (Prefix, Sorfix, Elfâz-1 Müştereke), Fransız Lisanına Mahsus İfade, Tashih-i Mükâleme, Ezber, Terkib-i İbare (Mekâtib ve Hikâyât ve ilh.), Asâr-1 Müntehibe (Mekâtib, Tarih, Edebiyat, Usul-i İdare), Mükâlemât ve Mekâtib-i Müsta'mele'nin Fransızca'dan Türkçe'ye Tercümesi.

Dördüncü Sınıf: Tahlil-i Nahvi, Elfâz-1 Müterâdife, Nahv (İstisnâ'at), Üslûb ve Terkib-i İbare, Üslûb ve Mecâzât ve İsti'ârât Kavanini, Asâr-1 Müntehibe, Ta'lim-i Mekâtib, Muhâberât, Usul-i İdareye Dair Raporlar, Asâr-1 Müntehibe, Raporlar, Arzuhaller, Tarih, İlm-i Servet, Usul-i İdare, Hukuk-1 Düvel, Mu'âhedât, Evrak-1 Siyasiyye, Fesâhata Dair Asâr, Usul-i İdareye Mahsus Nümûne-i Muhâberât, Aynı Mevaddın Fransızcası'ndan Türkçe'ye ve Türkçe'den Fransızca'ya Tercümesi.

Beşinci Sınıf: Belâgatın Müntehâ-yı Tahsili, Usul-i Müzâkerât, ve Muhâkemât Tahsili, Kavâid-i Belâgatın Fransız Lisanına Tatbiki, Terkib-i İbare, Redd-i Cevab ve Hitâb Tecrübeleri, Mesâil-i İlmiyeye ve Fenniyeye

${ }^{60}$ BOA, Ayniyât Defteri, No: 1567, 26 R 1303/ 20 Kanun-1 Sani 1301/ 2 Şubat 1886, s. 291.

${ }^{61}$ Sâlnâme-i Nezaret-i Hariciye 1301, Osmanlı Dışş̧̧leri Bakanlığı Yıllığı, (yay.haz. Ahmet Nezih Galitekin), İstanbul 2003, s. 459; 1303 ve 1304 sâlnâmelerinde okulun kadrosu Müdür Nebih Efendi, yedi muallim ve iki hademeden oluşmaktadır. 1303 Sâlnâme-i Devlet-i Aliyye-i Osmaniye, Mahmud Bey Matba'ası, İstanbul 1303, s. 322; 1304 Sâlnâme-i Devlet-i Aliyye-i Osmaniye, Mahmud Bey Matba'ası, İstanbul 1304, s. 310. 
Dair Nutuklar, Dördüncü Sınıf Derslerinin İkmâli, Aynı Mevaddın Fransızcası'ndan Türkçe'ye ve Türkçe'den Fransızca'ya Tercümesi' ${ }^{62}$.

$\mathrm{Bu}$ ders programından anlaşıldığı gibi Lisan Mektebi'nde Fransızca gramer ve tercümeleri, konuşma ve yazma başta olmak üzere tarih, coğrafya, edebiyat, kamu yönetimi, uluslararası anlaşmalar, devletler hukuku, ekonomi gibi geniş bir perspektifi kapsayan dersler okutulmuştur.

1306 Hariciye Salnamesi'nde de yukarıda verilen derslerin dışında Lisan Mektebi'nin programına Fransızca'nın yanı sıra tarih ve coğrafya derslerine daha çok ağırlık verildiği anlaşılmaktadır. Eskiçağ Tarihi (Tarih-i Kadim), Roma ve Kurun-1 Vusta Tarihi, Yakınçağ Tarihi (Ezmine-i Cedide Tarihi), Avrupa, Afrika, Amerika, Avustralya, Asya ve Osmanlı coğrafyaları okutulmuştur. ${ }^{63}$ Yine bu salnameye göre ${ }^{64}$ okulun öğrenci sayısı 225 'tir. Okulun öğretmen kadrosu da Müdür Mehmed Refik Bey ${ }^{65}$; Usul-i Tercüme Muallimleri Ohannes Efendi ile Yusuf Behçet Efendi; Lisan-1 Fransevi Muallimleri Mösyö Perar (Pirar), Mösyö Döbova, Ahmed Ata Bey, Kostantin Efendi, Kostaki Efendilerden ${ }^{66}$ oluşmaktadır.

\footnotetext{
${ }^{62}$ Sâlnâme-i Nezaret-i Hariciye 1301, s. 460.

${ }^{63} 1306$ Hariciye Nezareti Sâlnâmesi, s. 658-659; Birinci Sınıf: Mebadi'-i Sarf, Mücmelet-i Müfreze, Talim-i Tahriri ve Şifahi, Efal-i Kıyasiyye ve En Ziyade Müstamel Olan Bazı Efal-i Semaiyye, Kıraat, Mükaleme, İkinci Sınıf: Birinci Sınıf Derslerinin Hulaseten Rüyeti, Cem' ve Müiennesin Teşkiline Dair Kavaidin İstisna'âtı, Sıfatlarda Ma'nanın Derecatı, Zamair Hakkında Tenbihat, Efâlde Teşekkül-i Ezmine, Ef'âle Dair Tenbihat, Efal-i Mensube, Efal-i Semaiye ve Bazı Efal-i Nakise, Kıraat, Suret-i İbtidaiyede Dikte, Mebadi-i Tarih ve Coğrafya, Mükaleme, Üçüncü Sınıf: İkinci Sınıf Derslerinin Hulaseten Rüyeti, İsim ve Sıfatların Tetimmatı, Müteallikat-1 Efal, Tahlil-i Mükemmel-i Nahvi, Tahlil-i Mantıki, İsm-i Fail ve Mefullerin İmlası, Elfaz-1 Mütesabihe ve Mütearife ve Müştakka ve Mürekkebe, Mana-yı Hakiki ve Mecazi, Mecazat-1 Sarfiyye, Kıraat-1 Müdellele, Mekatib, Hikayat, Tarih-i Kadim, Avrupa ve Afrika ve Amerika'nın Coğrafya-yı Tabiiyye ve Siyasiyyesi, Dördüncü Sınıf: Tahlil-i Mantıki, Üslub, Üslub-1 Adi, Üslub-1 Tarif, Hikayat-1 Mekatib, Usul-i İnşa, Roma ve Kurun-1 Vusta Tarihi, Asya ve Amerika Coğrafyası, Fransızca'dan Türkçe'ye Tercüme, Beşinci Sınıf: Usul-i Kavaid-i Belagat, İcad, Tabirat-1 Mahsusa, Üslub-1 Mutedil ve Ali, Usuli Kitabet-i Siyasiyye, Tatbikat, Mesail-i Edebiyye ve Tarihiyye ve Sairenin Tafsil ve Tavzihi, Asar-1 Müntehibe-i Siyasiyye, Ezmine-i Cedide Tarihi, Okyanus ve Memalik-i Osmaniye Coğrafyası, Fransızca'dan Türkçe'ye ve Türkçe'den Fransızca'ya Tercüme.

${ }^{64} 1306$ Hariciye Nezareti Sâlnâmesi, s. 658-659.

${ }^{65}$ Mehmed Refik Bey, aynı zamanda Tercüme Odası Evrak Müdürüdür. Mehmed Refik Bey mektebin hal-i intizamına ve tedrisatın usulü zımnında dairesine devama dikkat eylediği için ula sınıf-1 sani rütbesine terfi' ettirilmiştir. BOA, İrade Hariciye, 20578, 28 R 1300.

${ }^{66}$ Lisan Mektebinin yukarıda bahsedilen müdür ve hoca kadroları 1305 Devlet Sâlnâmesi ile de aynıdır. 1305 Sâlnâme-i Devlet-i Aliyye-i Osmaniye, Mahmud Bey Matbaası, İstanbul 1305, s. 232-233.
} 
Okulun 1892 sonunda yapılan sınavlarında Maarif Nezareti tarafından görevlendirilen Sırrı Bey, özellikle son sınıf öğrencilerinin çok iyi Fransızca öğrenmiş olduklarını belirtmiş ve bu öğrenciler içinde Fatih Polis Komiseri olan Osman Efendi'nin adını vermiştir. Yine aynı belgede Sırrı Bey okulun ders programına Arapça ve Farsça'nın eklenmesinden duyulan memnuniyeti de dile getirerek okula yakın bir zamanda Almanca, Rusça ve İngilizce sınıflarının açılacağını da belirtmiştir. ${ }^{67}$

\section{Lisan Mektebi'nin Kapatılması}

Birçok defa açılıp kapatılan Lisan Mektebi'nin bir daha açılmamak üzere kapatılması 18 Ağustos 1892'de Hariciye Nazırı Mehmet Sait Paşa ve Sadrazam Cevat Paşaların ortak bir tezkeresi ile olmuştur. Tezkerenin yazılma tarihi ile onaylanması aynı günde olmuştur. Kapatılma gerekçesi olarak okula bir hayli masraf yapıldığı ve okulun istenilen derecede başarılı olamadığı ifade edilerek kapatılmasına ve yerine Mekteb-i Ali-i Diplomasi adıyla başka bir okulun açılmasına karar verilmiştir. ${ }^{68}$ Ergin, okulun hemen kapatılmasının sebebini Padişah'a yazılan bir jurnaldan kaynaklandığını söylemektedir. Buna göre Lisan Mektebi'ne öğrencilerin devamı sağlamak için sene başlarında Sadaret tarafından bütün bakanlık ve dairelere bir genelge gönderilerek memurların okula gitmelerinin teşvik edilmesi, devam edenlere de kolaylık gösterilmesi tavsiye edilirmiş, bu sırada bu genelgenin yanlışlıkla Şeyhülislâm'lık dairesine yollanması bu jurnale sebeb olmuştur. Burada bulunan gelenekçi memurlardan birinin "talebe-i ulûm Fransızca öğrenmeye teşvik ve bu suretle gâvurluğa tergib olunuyorlar" şeklinde verdiği jurnal üzerine Lisan Mektebi kapatılmıştır. ${ }^{69}$ Ergin, bu jurnalin Meşihât Mektupçusu Cemaleddin Efendi tarafından verildiğini iddia etmektedir. Jurnal meselesi hakkında elimizde Rıdvan Paşa'nın 12 Eylül 1892 tarihli bir yazısı bulunmaktadır. Bu yazıdan Lisan Mektebi'nin kapatılması hakkında bazı ipuçları bulmak mümkündür. Rıdvan Paşa, yazısında bütün okullarda Fransızca dersinin okutulduğunu, Lisan Mektebi'nde okuyacak olan öğrencilerin sadece yabancı dillerde iş gören memuriyetlere ait olmaları gerektiğini ve bunun Bab-1 Fetva gibi dairelere yayılmasının uygun olmadığını ve özellikle Bab-ı Fetva ile

\footnotetext{
${ }^{67}$ BOA, Yıldız Tahrirat-ı Ecnebiye ve Mabeyn Mütercimliği, 26/9, 14 Muharrem 1310/7 Ağustos 1892, Sırrı Bey'in arzuhali.

${ }^{68}$ Ergin, a.g.e., c. 2 ,s.539.

${ }^{69}$ Ergin, a.g.e., c.2, s.539; Bazı araştırmacılar okulun kapatılma tarihini 11 Eylül 1892 olarak vermişlerdir. Sakaoğlu, a.g.e., s.355; Unat, a.g.e., s.149, n. 54 ; Okulun kapatılmasından sonra konu belgelere “mülga Lisan Mektebi” olarak yansımıştır. 13 Eylül 1892'de Lisan Mektebi ile Hariciye kalemlerine alınan sobaların bedeli olan 8521,5 kuruş ödenmesi ile ilgili olan bir irade okulun bu tarihte resmen kapatılmadığını da göstermektedir, BOA, İrade Hariciye, 21 S 1310/13 Eylül 1892.
} 
askeriye memurlarının okula devam etmelerinin tezkere ile teşvik edilmemesi gerektiğini bildirmektedir. ${ }^{70}$

Lisan Mektebi yerine açılması düşünülen Mekteb-i Ali-i Diplomasi’nin Beşiktaş'ta açılması için hazırlıklar yapılmışsa da daha sonra bu teşebbüsten de vazgeçilmiştir. ${ }^{71}$ Bundan sonra Darülfünûn'da bir şube olmak üzere yeni bir Lisan Mektebi daha açılmasına karar verilmişse de ${ }^{72}$ yaptığımız araştırmalarda böyle bir okulun varlığı ile ilgili bir bilgiye ulaşamadık. Böylece yazımızın başında belirttiğimiz gibi yabancı dil konusundaki taassup XX. yüzyılın başlarına kadar devam etmiştir.

Okulun bütçesi Hariciye Nezareti'ne ait olduğu için okul kapatıldıktan sonra, okuldan açıkta kalan para ${ }^{73}$ için birçok memur maaşlarına ilave zam için dilekçeler vermişlerdir. Okul bütçesinin dört bini Dahiliye Nezareti'ne, altı bini Hariciye Nezareti'ne, 4500 kuruşu da Babıâli Sadaret Mektûbi ve Evrak kalemlerine ayrılmıştır. ${ }^{74}$

\section{Sonuç}

Osmanlı Devleti'nde yabanc1 dil bilgisi gerektiren memuriyetlere 1820'lerin başlarında Yahya Naci Efendi ve Başhoca İshak Efendi gibi mühtediler getirilmiştir. Böylece yabancı dil bilen Müslüman memurların yetiştirilmesine çalışılmıştır. Tanzimat dönemi reformlarını hayata geçiren Ali, Fuat, Ahmet Vefik, Safvet, Ahmed Arifi, Münif paşalar, Tercüme Odası'ndan yetişmişlerdir. Fakat Babıâli Tercüme Odası'nın zamanla, Osmanlı Devleti'nin idari teşkilatında yabancı dil öğretilen bir okul olma misyonunu yitirmesiyle Lisan Mektebi açılmıştır. Bu makalemizde Osmanlı modernleşmesi içinde açılması temel bir ihtiyaçtan kaynaklanan Lisan Mektebi'ni inceledik. Okulun birkaç defa açılıp kapatılması, Osmanlı Devleti'nin Batılılaşma teşebbüslerinde bir sistem eksikliğini açıkça ortaya koymuştur. $\mathrm{Bu}$ durum okulun tarihi gelişimi içinde bariz bir şekilde

${ }^{70}$ BOA, Yıldız Esas Evrakı, 14/90, 20 Safer 1310/12 Eylül 1892.

${ }^{71}$ Ergin, a.g.e., c. 2,s. 541.

${ }^{72}$ Ergin, a.g.e., c. 3 , s. 1051 .

${ }^{73}$ Okula ayrılan yıllık ödenek 1306'da 129.600 kuruştur. 1306 Hariciye Salnamesi, s. 634.

${ }^{74}$ BOA, Yıldız Adliye ve Mezahip Nezareti Maruzatı, 6/44, 18 Kanun-1 Evvel 1308/30 Aralık 1892, Hariciye Müsteşarı Artin Efendi'nin kendi maaşına ilave zam talebi; Lisan Mektebi tahsisatından 565 kuruşun Mektebi Sultani mezunu olan ve halen Tercüme Odası'nda çalışan damadı Rıfat Bey'e verilmesi için Mahkeme-i Temyiz Azası Hüseyin Hamid imzalı, BOA, Yıldız Adliye ve Mezahip Nezareti Maruzatı, 6/80 ve yine aynı kişi tarafından BOA, Yıldız Adliye ve Mezahip Nezareti Maruzatı, 6/44, 25 Kanun-1 Evvel 1308/6 Ocak 1893; Lisan Mektebi tahsisatından 200 kuruşun Hariciye Nezareti Tercümanı olan Mikail Efendi'nin maaşına ilavesi, BOA, Yıldız Mabeyn Başkitâbeti, 28/93, 6 Cemaziyelahir 1310/26 Aralık 1892 ve yine Mikail Efendi'nin maaşına 200 kuruşluk zam ilavesi için BOA, Yıldız Sadaret Resmi Maruzat, 6 Cemaziyelahir 1310/26 Aralık 1892. 
durmaktadır. Bununla birlikte Lisan Mektebi'nden Halil Hamid Paşazade Hamid Bey, ${ }^{75}$ Mustafa Mazhar Bey, ${ }^{76}$ Fatih Polis Komiseri Osman Efendi, ${ }^{77}$ Karakin Hasruyan Efendi, ${ }^{78}$ Rakım Açıkalın, ${ }^{79}$ Ali Fuat Bey (Türkgeldi), ${ }^{80}$ Rauf Yekta Bey, ${ }^{81}$ Mustafa Enver Bey, ${ }^{82}$ Adil Bey, ${ }^{83}$ Mustafa Fazil Bey, ${ }^{84}$ Güney Afrika'da ilk Türk diplomatı olan Mehmed Remzi Bey ${ }^{85}$ gibi isimler yetişmiştir.

\section{Kaynaklar}

1. Arşiv Belgeleri

BOA, Ayniyât Defterleri, No: 1254, 1567,1568.

BOA, Mühimme Defteri, No: 241.

BOA, Nezaret Gelen-Giden Defterleri, No: 396.

BOA, Cevdet Maliye, No: 21602.

BOA, Hatt-ı Hümâyûn, No: 1374, 24621, 34965 A,

BOA, İrade Dahiliye, No: 38078, 39585, 71685, 74216, 74643.

BOA, İrade Hariciye, No:18703, 20578, 21 S 1310/13 Eylül 1892.

BOA, İrade Meclis-i Vâlâ, 26127.

BOA, Sadaret Mektûbî Mühimme, No: 395/94, 431/100, 352/35, 385/70, 386/60, $419 / 25,434 / 29$

BOA, Şura-yı Devlet, No: 209/55.

BOA, Yıldiz Esas Evrakı, No: 14/90.

BOA, Yıldız Mabeyn Başkitâbeti, No: 28/93.

BOA, Yıldız Sadaret Resmi Maruzat, No: 6 Cemaziyelahir 1310/26 Aralık 1892.

BOA, Yıldız Adliye ve Mezahip Nezareti Maruzatı, No: 6/44.

\footnotetext{
${ }^{75}$ Meclis-i Vâlâ azalığından ayrılma Nurullah Bey'in oğludur. Lisan Mektebi’nden sonra Babıâli Tercüme Odası'na girdi. Behice Sultan'la evlendi. Şura-yı Devlet azası oldu. 20 Kasım 1888'de öldü. Mehmed Süreyya, Sicill-i Osmanî Osmanlı Ünlüleri, (yay. haz. Nuri Akbayar), İstanbul 1996, c. 2, s. 597.

761291 İstanbul doğumlu, Numune-i Terakki Mektebi'nde, Lisan Mektebi’nde okudu. Babıâli Tercüme Kalemi'ne devam etti. Okullara mahsus olarak basılmış bazı eserleri, gazete ve dergilerde hikâye ve makaleleri vardır, Hüseyin Vassaf, Nevsâl-i Asr (1313), Cemaleddin Matbaası, İstanbul 1314, s. 208.

${ }^{77}$ BOA, Yıldız Tahrirat-ı Ecnebiye ve Mabeyn Mütercimliği, 26/9, 14 M 1310/7 Ağustos 1892, Sirr1 Bey'in arzuhali.

${ }^{78}$ Fransizca, İngilizce, Bulgarca bilen ve Lisan Mektebi mezunu olan Karakin Hasruyan Efendi Ankara Vilayeti Tercümanlığı'na atandı, BOA, Dahiliye Nezareti, Muhaberât-ı Umumiye İdaresi, 22-1/9, 20 Ağustos 1325/2 Eylül 1909.

${ }^{79}$ Biyografisi için bkz. BOA, SA, No:93, s. 177'den nakleden Ali Çankaya, Mülkiye Tarihi ve Mülkiyeliler, Ankara 1954, c. 1, 262-263.

${ }^{80}$ Son Sadaret Müsteşarı ve Rical-i Mühimme-i Siyasiye'nin yazarı, Ergin, a.g.e., c. 2, s. 541

${ }^{81}$ Ergin, a.g.e., c. 2, s. 541.

${ }^{82}$ Telgraf Müdürü, Süheyl Ünver'in babas1, Ergin, a.g.e., c. 2, s. 541.

${ }^{83}$ Ergin, a.g.e., c. 2, s. 541 .

${ }^{84}$ Ergin, a.g.e., c. 2, s. 541

${ }^{85}$ Arşiv belgelerine dayalı bir biyografisi için bkz. Ahmet Uçar, " Güney Afrika'da İlk Türk Diplomat Mehmet Remzi Bey”, www.biyografi.net/kisiayrinti.asp.
} 
BOA, Yıldız Adliye ve Mezahip Nezareti Maruzatı, 6/80.

BOA, Dahiliye Nezareti, Muhaberât-ı Umumiye İdaresi, No: 22-1/9.

BOA, Yıldız Tahrirat-ı Ecnebiye ve Mabeyn Mütercimliği, 26/9.

Düstûr, c. 4, Matba'a-i Osmaniye, Dersaadet 1302.

\section{Eserler}

Adıvar, Adnan, Osmanlı Türklerinde İlim, Remzi Yay., İstanbul1970.

Akyıldız, Ali, Osmanlı Merkez Teşkilatında Reform (1836-1856), Eren Yay., İstanbul 1993.

Atar, Fahreddin, İslâm Adliye Teşkilatı, Ankara 1979.

Balcı, Sezai, Osmanlı Devleti'nde Tercümanlık ve Babıâli Tercüme Odası, (Ankara Üniversitesi Sosyal Bilimler Enstitüsü, Yayınlanmamış Doktora Tezi), Ankara 2007.

Bacque-Grammont, Jean Louis, "Feridun Bey'in Az Bilinen Bir Yapıtı "Tevârih-i Padişahân-ı Françe" Üzerine Bazı Düşünceler”, XII. Türk Tarih Kongresi, Ankara 12-16 Eylül 1994, Kongreye Sunulan Bildiriler, (çev. Aksel Tibet), c. 4, Türk Tarih Kurumu Yay., Ankara 1999.

Başbakanlık Osmanlı Arşivi Rehberi, Devlet Arşivleri Genel Müdürlüğü Yay., 2. bask1, İstanbul 2000.

Berkes, Niyazi, Türkiye'de Çağdaşlaşma, (haz. Ahmet Kuyaş), Yapı Kredi Yay., 4. baskı, İstanbul 2003.

Beydilli, Kemal, Türk Bilim ve Matbaacılık Tarihinde Mühendishane, Mühendishane Matbaası ve Kütüphanesi (1776-1826), Eren Yay., İstanbul 1995 .

Beydilli, Kemal-İ. Şahin, Mahmut Raif Efendi ve Nizam-ı Cedid'e Dair Eseri, Ankara 2001.

Ceyhan, Erdal, Türk Eğitim Tarihi Kronolojisi, Ulusal Bellek Yay., Edirne 2004

Çankaya, Ali, Mülkiye Tarihi ve Mülkiyeliler, c. 1, Ankara 1954.

Çark,Y. G., Türk Devleti Hizmetinde Ermeniler, İstanbul 1953.

Düzdağ, Mehmet Ertuğrul, Şeyhülislâm Ebussuud Efendi Fetvaları Işı̆̆ında 16. Asır Türk Hayatı, Enderun Yay., İstanbul 1972.

Ergin, Osman Nuri, İstanbul Mektepleri ve İlim Terbiye ve Sanat Müesseseleridolayısıyla-Türkiye Maarif Tarihi, c. 2-3, Osman Bey Matbaası, İstanbul 1940-1941.

Faroqhi, Suraiya, Osmanlı Kültürü ve Gündelik Yaşam, (çev. Elif Kılıç), 4. baskı, İstanbul 2002.

Fatma Aliye, Ahmet Cevdet Paşa ve Zamanı, Kanaat Matbaası, Dersa'adet 1332, s. 34 (eserin yeni harflerle baskısı Metin Hasırcı tarafından yapılmıştır. İstanbul 1994).

Findley, Carter, "The Foundation of the Ottoman Foreign Ministry", International Journal of Middle East Studies, 3/1972, s.388-416.

Findley, V. Carter, Kalemiyeden Mülkiyeye Osmanlı Memurlarının Toplumsal Tarihi, (çev. Gül Çağalı Güven), İstanbul 1996. 
Findley,Carter V., Osmanlı Devletinde Bürokratik Reform Babıâli (1789-1922), (çev. Latif Boyacı-İzzet Akyol), İz Yay., İstanbul 1994.

Fleischer, Cornell H.,Tarihçi Mustafa Ali Bir Osmanlı Aydın ve Bürokratı, (çev. Ayla Ortaç), 2. baskı, İstanbul 2001.

Gerçek, Selim Nüzhet, Türk Matbaacılığı Müteferrika Matbaası, İstanbul 1939.

Göçek, Fatma Müge, Burjuvazinin Yükselişi İmparatorluğun Çöküşü Osmanlı Batılaşması ve Toplumsal Değişme, çev. İbrahim Yıldız, Ayraç, Ankara 1999.

Güner, Osman, Resülullah'ın Ehl-i Kitapla Münasebetleri, Fecr, Ankara 1997.

Hezarfen Hüseyin Efendi, Telhisü'l-Beyân fi Kavanin-i Âl-i Osman, (haz. Sevim İlgürel), Türk Tarih Kurumu Yay., Ankara 1998.

Hüseyin Vassaf, Nevsâl-i Asr (1313), Cemaleddin Matbaası, İstanbul 1314.

Işıksal, Cavide, “Türkiye'de Açılan İlk Yabancı Dil Okulları”, Belgelerle Türk Tarihi Dergisi, VII/May1s 1968, s. 29-31.

İnalcık, Halil, Doğu Batı, Makaleler I, Doğu Batı Yay., 2. baskı, Ankara 2005.

Karal, Enver Ziya, Osmanlı Tarihi, c. 5-7, 6. baskı, Türk Tarih Kurumu Yay., Ankara 1994-1995.

Kayaoğlu, Taceddin, Türkiye'de Tercüme Müesseseleri, Kitabevi Yay., İstanbul 1998.

Köprülü, M. Fuad, “Asım Efendi”,İslam Ansiklopedisi, c.1, İstanbul 1995, s. 670.

Kuran, Ercüment, Avrupa'da Osmanlı İkamet Elçiliklerinin Kuruluşu ve İlk Elçilerin Siyasi Faaliyetleri (1793-1821), Türk Kültürünü Araştırma Enstitüsü Yay., Ankara 1968.

Kütükoğlu, Bekir, Vekayinüvis, Makaleler, İstanbul 1994.

Lewis, Bernard, Çatışan Kültürler, Keşifler Çağında Hristiyanlar, Yahudiler, Müslümanlar (çev. Nurettin Elhüseyni), İstanbul 1997.

Lewis, Bernard, İslâm Dünyasında Yahudiler, (çev. Bahadır Sina Şener), İmge Yay., Ankara 1996.

Lewis, Bernard, Modern Türkiye’nin Doğuşu, (çev. Metin Kıratlı), 8. Baskı, Türk Tarih Kurumu Yay., Ankara 2000.

Lewis, Bernard, Müslümanların Avrupa'yı Keşfi, (çev. İhsan Durdu), Ayışı ̆̆ Yay.,İstanbul 2000.

Lyber, Albert Howe, Kanuni Sultan Süleyman Döneminde Osmanlı İmparatorluğu'nun Yönetimi, (çev. Seçkin C1lızoğlu), İstanbul 2000.

Mehmed Süreyya, Sicill-i Osmanî Osmanlı Ünlüleri, c. 2, (yay. haz. Nuri Akbayar), Kültür Bakanlığı-Tarih Vakfı Yay., İstanbul 1996.

Ortaylı, İlber, "Osmanlı Diplomasisi ve Diş İşleri Örgütü”, Tanzimattan Cumhuriyete Türkiye Ansiklopedisi, c. 1, s. 278-281.

Ortaylı, İlber, İmparatorluğun En Uzun Yüzyılı, Hil Yay., 3. baskı, İstanbul 1995.

Pamukciyan, Kevork "Manas Ailesi", Dünden Bugüne İstanbul Ansiklopedisi, c.5, İstanbul 1994, s. 286-287.

Sakaoğlu, Necdet, Osmanlı'dan Günümüze Eğitim Tarihi, İstanbul Bilgi Üni. Yay., İstanbul 2002. 
Sâlnâme-i Devlet-i Aliyye 1286 (1869), Darüt-Tıbaatil Amire Matba'ası, İstanbul 1286.

Sâlnâme-i Devlet-i Aliyye 1287 (1870) , Darüt-Tibaatil Amire Matba'ası, İstanbul 1287 .

Sâlnâme-i Devlet-i Aliyye-i Osmaniye 1284 (1867), Darüt-Tibaatil Amire Matba'ası, İstanbul 1284.

Sâlnâme-i Devlet-i Aliyye-i Osmaniye 1285 (1868), Darüt-Tıbaatil Amire Matba'ası, İstanbul 1285.

Sâlnâme-i Devlet-i Aliyye-i Osmaniye 1303, Mahmud Bey Matba'ası, İstanbul 1303.

Sâlnâme-i Devlet-i Aliyye-i Osmaniye 1304, Mahmud Bey Matba'ası, İstanbul 1304.

Sâlnâme-i Devlet-i Aliyye-i Osmaniye 1305, Mahmud Bey Matbaası, İstanbul 1305.

Sâlnâme-i Nezaret-i Hariciye 1301, Osmanlı Dışişleri Bakanlığı Yıllığı, (yay. haz. Ahmet Nezih Galitekin), İşaret Yay., İstanbul 2003.

Salname-i Nezaret-i Hariciye 1306, Osmanlı Dışişleri Bakanlığı Yıllığı, (yay. haz. Ahmet Nezih Galitekin), İşaret Yay., İstanbul 2003.

Sarıcaoğlu, Fikret, "Şeyh Mehmet İhlasî", Türkiye Diyanet Vakfı İslam Ansiklopedisi, c. 21, s. 538-539.

Sayar, Ahmet Güner, Osmanlı İktisat Düşüncesinin Çağdaşlaşması, 2. baskı, Ötüken Yay., İstanbul 2000.

Sönmez, Abidin, Resülullah'ın Diplomatik Münasebetleri, İnkılâp Yay., İstanbul 1984.

Tanpınar, Ahmet Hamdi, Edebiyat Üzerine Makaleler, (haz. Zeynep Kerman), MEB, İstanbul 1969.

Turan, Şerafettin "Venedik'te Türk Ticaret Merkezi, Fondaco dei Turchi, Belleten, 126/Nisan 1968, s. 247-275.

Uçar, Ahmet, "Güney Afrika'da İlk Türk Diplomat Mehmet Remzi Bey", www.biyografi.net/kisiayrinti.asp

Uluçay, Çağatay-Enver Kartekin, Yüksek Mühendis Okulu, Berksoy Matbaası, İstanbul 1957.

Unat, Faik Reşit, Türkiye Eğitim Sisteminin Gelişmesine Tarihi Bir Bakış, MEB, Ankara 1964.

Ülken, Hilmi Ziya, Uyanış Devirlerinde Tercümenin Rolü, Vakit Yay., İstanbul 1935.

Yirmisekiz Çelebi Mehmed Efendi'nin Sefaretnamesi, (yay. haz. Beynun Akyavaş), Türk Kültürünü Araştırma Enstitüsü Yay., Ankara 1993. 